\title{
Sediment Characteristic of Pagai Strait, Mentawai
}

\author{
Herdiana Mutmainah $^{1), \text { a) }}$ and Rini Kusumawardani ${ }^{2), b)}$ \\ ${ }^{1}$ Research Institute of Coastal Resources and Vulnerability. Ministry of Marine Affairs and Fisheries \\ Komp. PPS Bungus, Jl. Raya Padang Painan KM 16, Telp/Fax. 0751-751458. Teluk Bungus. \\ West Sumatera. Indonesia. \\ ${ }^{2}$ Civil Engineering Department, Universitas Negeri Semarang \\ a)Corresponding author: herdianamute77@gmail.com \\ b)rini.kusumawardani@mail.unnes.ac.id
}

\begin{abstract}
The marine sediment is important indicator of the seafloor. The characteristics of marine sediments can be seen from grain size, type and Total Dissolved Solid (TDS). Sediments derived from organic and non-organic particles are carried by the sea currents, waves, streams and tidal process in the coastal areas. At very high levels, sediments can cause pollution or vulnerability such as decreasing of dissolved oxygen, coral bleaching, and increased the eurotrification processes. Pagai Strait is located between North Pagai Island and South Pagai. This strait has enormous potential and it is used by the surrounding community for various activities such as port and sea transportation, fishery, marine aquaculture and tourism. This study aims to determine the characteristics of sediment in Pagai Strait. The field survey was conducted in September 2016 for waves, currents, water quality and sediment samples with purposive sampling method. The results showed that the average of sediments in Pagai Strait is D35 sized $0.155 \mathrm{~mm}$; D50 sized $0.273 \mathrm{~mm}$; and D90 sized 1.574 $\mathrm{mm}$ with specific gravity $2.665 \mathrm{gr} / \mathrm{cm} 3$ and dominated by sand $66.88 \%$. TDS between 51.6 to $55.0 \mathrm{mg} / \mathrm{L}$, appropriate for port and mangrove. Scale of sediment, $A=0.119$ and sediment velocity is $0.002 \mathrm{~m} / \mathrm{s}$. Sediment transport approximately is $0.389 \mathrm{~m} 3 /$ day.
\end{abstract}

Keywords : Sediment transport, grain size, TDS.

\section{INTRODUCTION}

The Pagai Strait is located between North Pagai Island and South Pagai Island, Mentawai Islands Regency. This area is located on the Indonesian Ocean and subduction path of active tectonic plates which are prone to earthquake and tsunami. Various activities and impacts of the Tsunami in $2010(7.7 \mathrm{Mw})$ caused certain characteristics in sediment. Sediment is formed by organic and non-organic materials. CEM (2002) classified sediments in two major classes: clay $(\phi<0.0039 \mathrm{~mm})$ and sand $(\phi \sim 0.0625-2.0 \mathrm{~mm})$ [1]. The sediment in Pagai Strait is combination between muddy sand and nummulite limestone. The depth of the strait is between $3 \mathrm{~m}$ to $55 \mathrm{~m}$. Most of the sediment is dominated by sand. The volume of sediment at the strait is influenced by the location also. This strait is estuary of eight rivers. The research aims to determine the type, grain size and sediment transport and also the distribution of parameters, including Total Dissolved Solid (TDS). TDS was used to indicate the water quality status. Figure 1 shows the location of Pagai Strait and Figure 2 shows the location of sediment samples. 


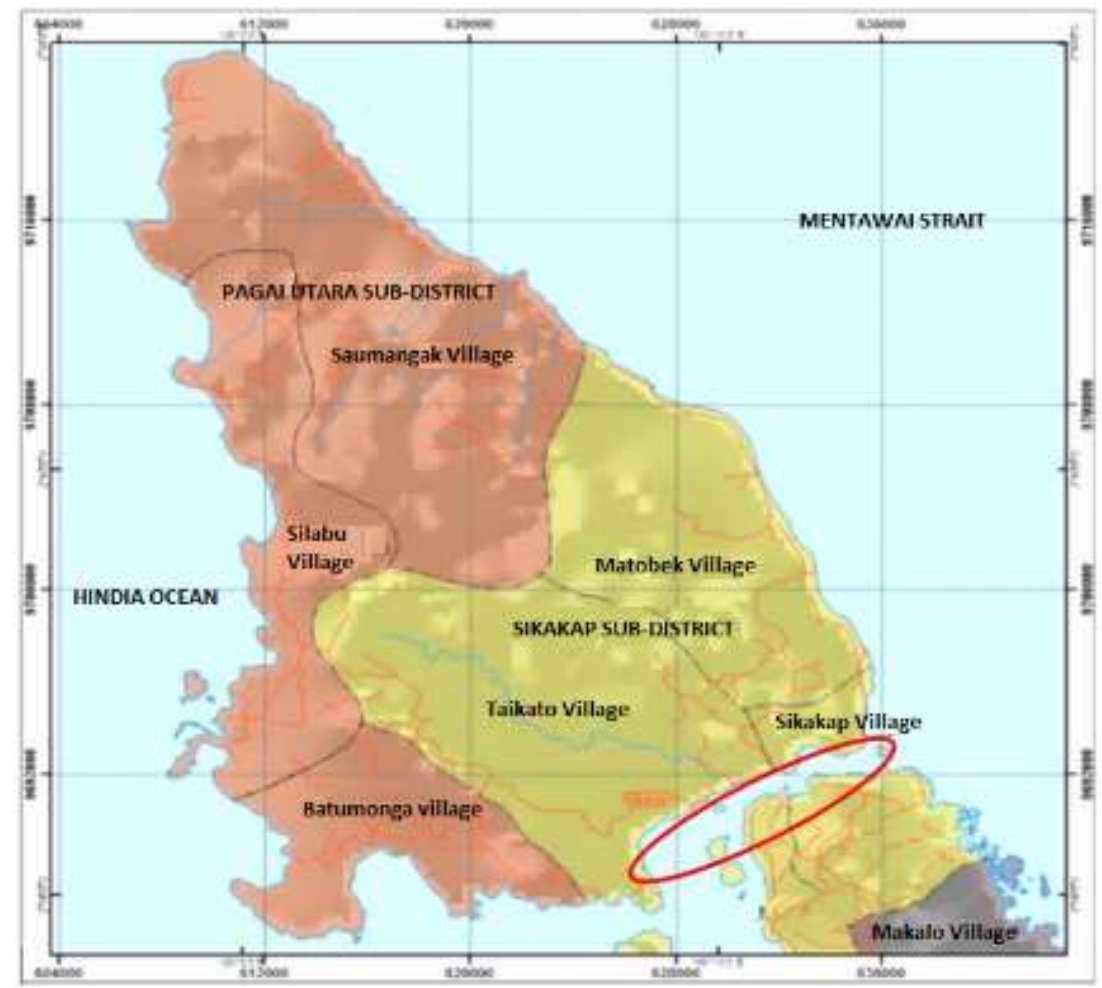

FIGURE 1. The Location of the Pagai Strait

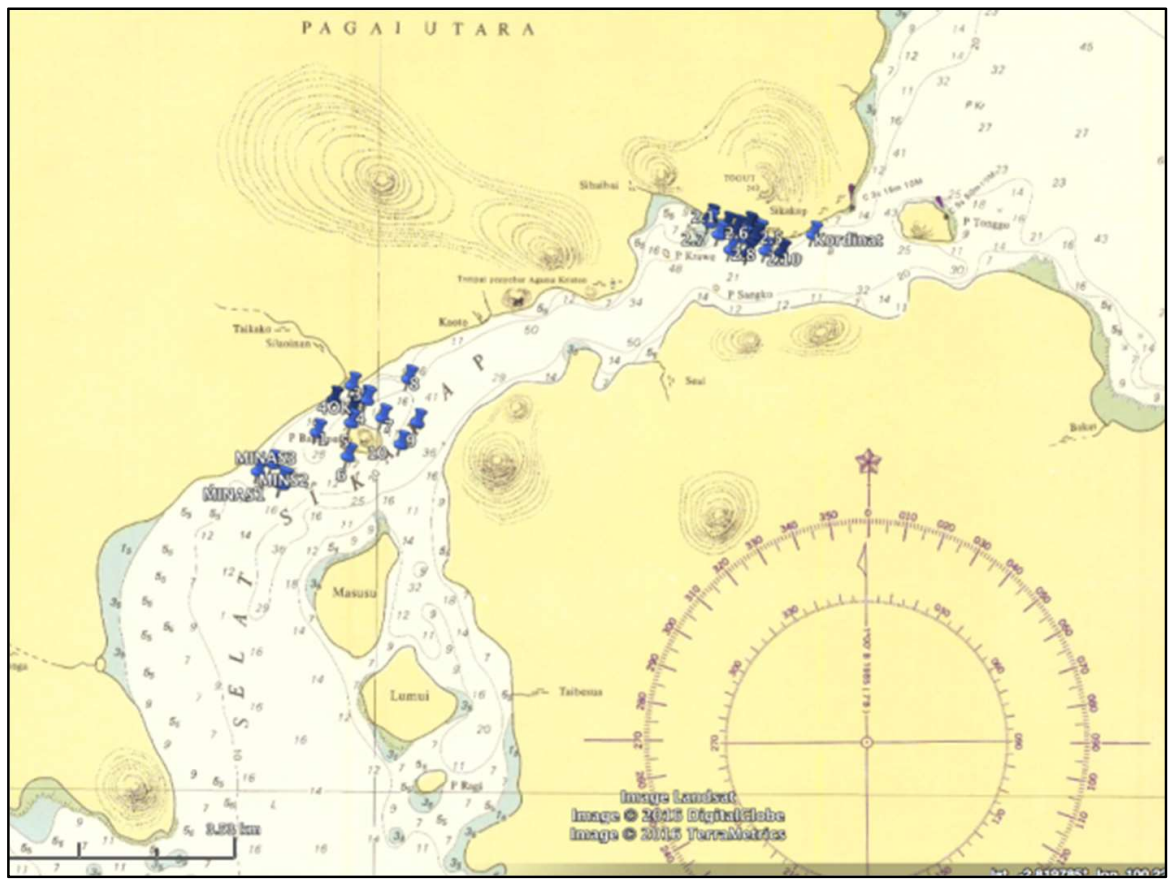

FIGURE 2. The Location of Sediment Samples 


\section{METHODOLOGY}

The survey of sediment characteristic in Pagai Strait was conducted on September 2016, on 23 sample points by purposive sampling using sediment grab, WQC TOAA and ADCP. The current was measured by ADCP, TDS by WQC TOAA and sediment grab for sediment samples. Grain size of soil particles and density/specific gravity were tested in soil mechanic laboratory at Civil Engineering Lab of Andalas University using soil sieve distribution analysis. With this method, it it could be find the value of $\mathrm{D}_{35}, \mathrm{D}_{50}$ and $\mathrm{D}_{90}$ in ASTM method. Distribution of soil particles diameter then were mapped using Ocean Data View (ODV).

\section{DISCUSSION}

Mechanism of sediment budget is a complex process of sediment. Sediment on rivers, ocean currents, tidal waves, storms, and any materials from the land is brought by the winds [2]. Complexity of coastal sediment is shown as Figure 3. In normal and balanced condition, the beach can gain and loss the sediment at the same periodical time. Mostly, the currents and waves trigger the phenomenon of sediment transport. Winds and storm contributed on the surface distribution of sediment. Sediment in Pagai Strait is a type of long-shore sediment because the currents direction is similar along the strait.

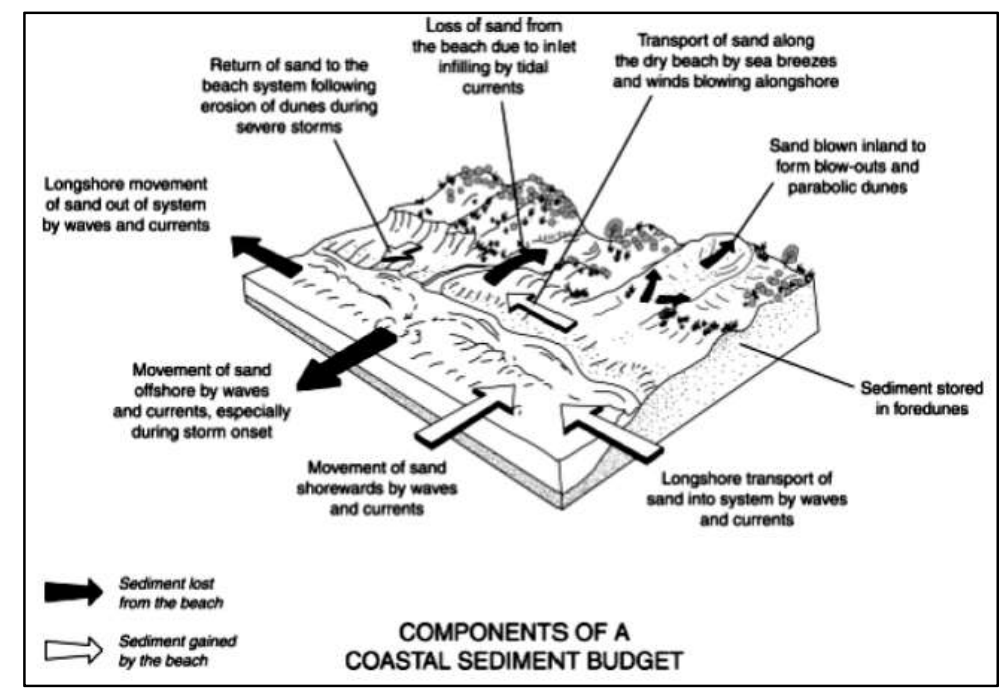

FIGURE 3. Mechanism of Coastal Sediment Budget [2] 


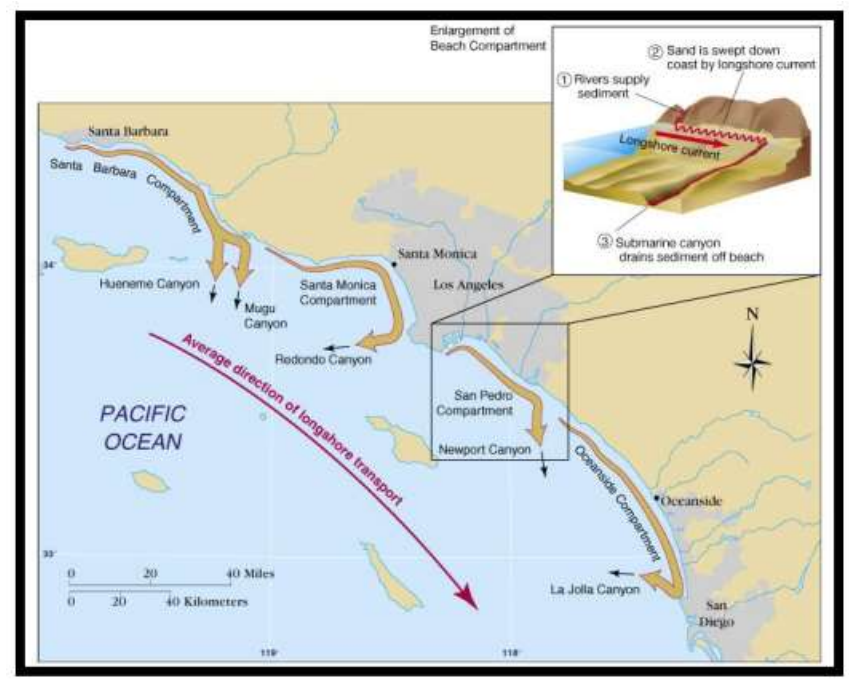

FIGURE 4. Ilustration of Longshore Sediment at Pacific Coastal [3]

People use the Pagai Strait in many ways such as fisheries, ports or transportation, tourism, aquaculture, domestic or daily needs, etc. Figure 4 below shows the population and activities along the Pagai Strait. Figure 5 shows the history of earthquake and tsunami at west water of Sumatera.
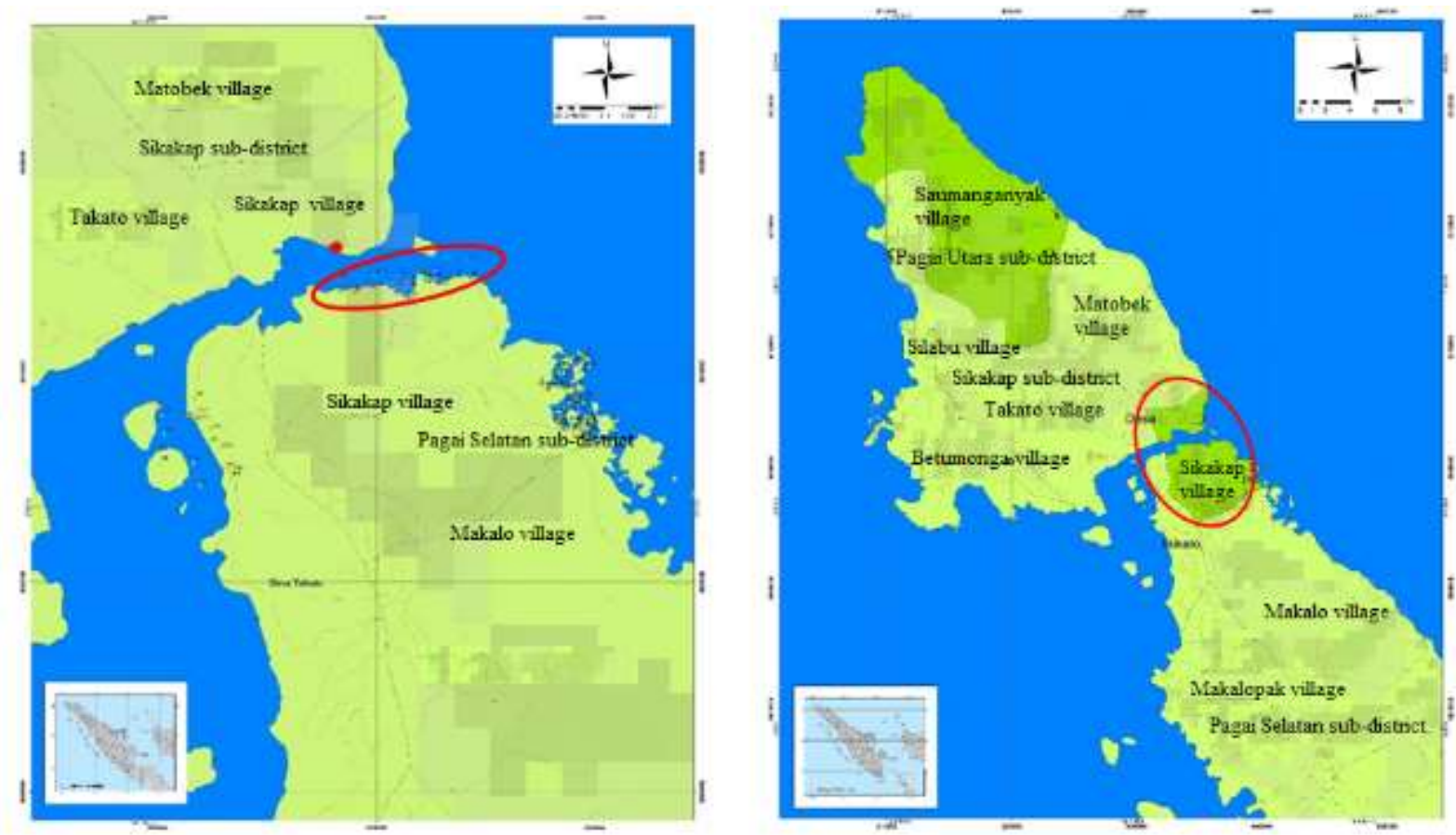

FIGURE 5. Activities and Population in around The Pagai Strait 


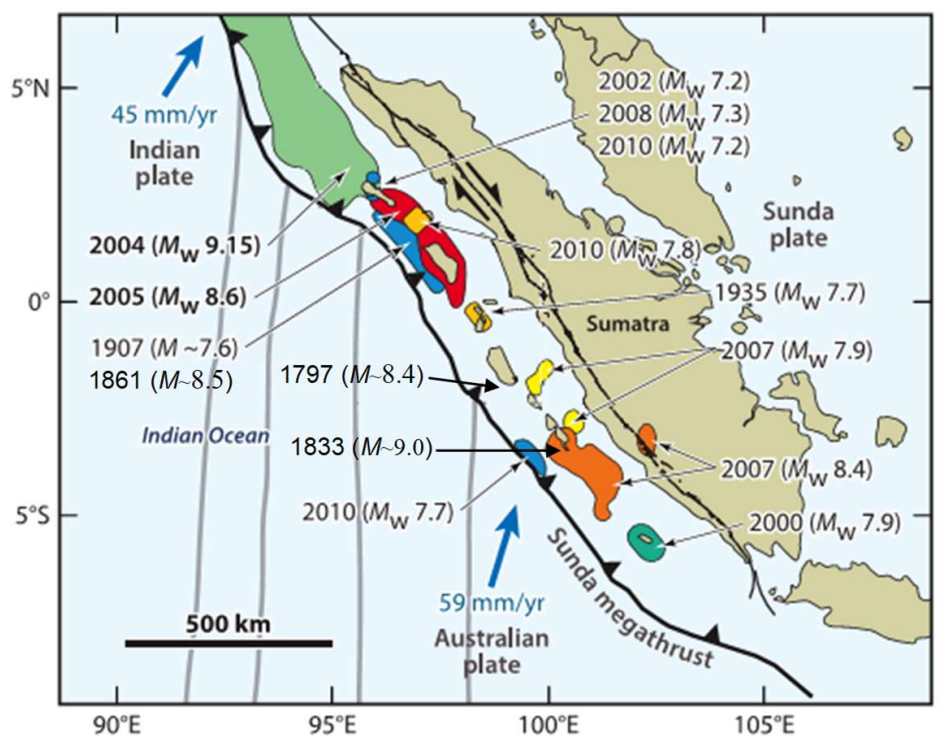

FIGURE 5. Map of the history of earthquake and tsunami at West Sumatera waters from [4], [5], [6] and [7]

On figure 5, as we can see, The Pagai Strait was hit by tsunami at least three times at year 1833 (9.0 Mw), 2007 (7.9 Mw and 8.4 Mw) and $2010(7.7 \mathrm{Mw}$ ). The bathymetry around The North Pagai Island is between $3 \mathrm{~m}$ to $55 \mathrm{~m}$. The Figure 6 below shows the bathymetry around The North Pagai Island and The Pagai Strait.

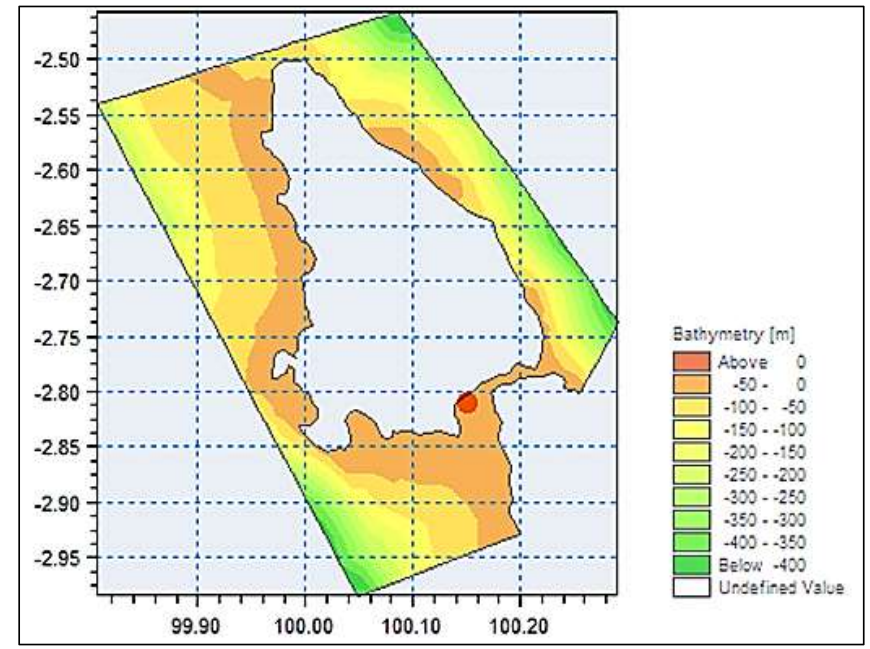

FIGURE 6. Bathymetry around The North Pagai Island and The Pagai Strait Strait [8]

The maximum current velocity is $0.13 \mathrm{~m} / \mathrm{s}$ and type of tidal is mixed tide prevailing semi diurnal tide $(\mathrm{F}=0.537)$. 

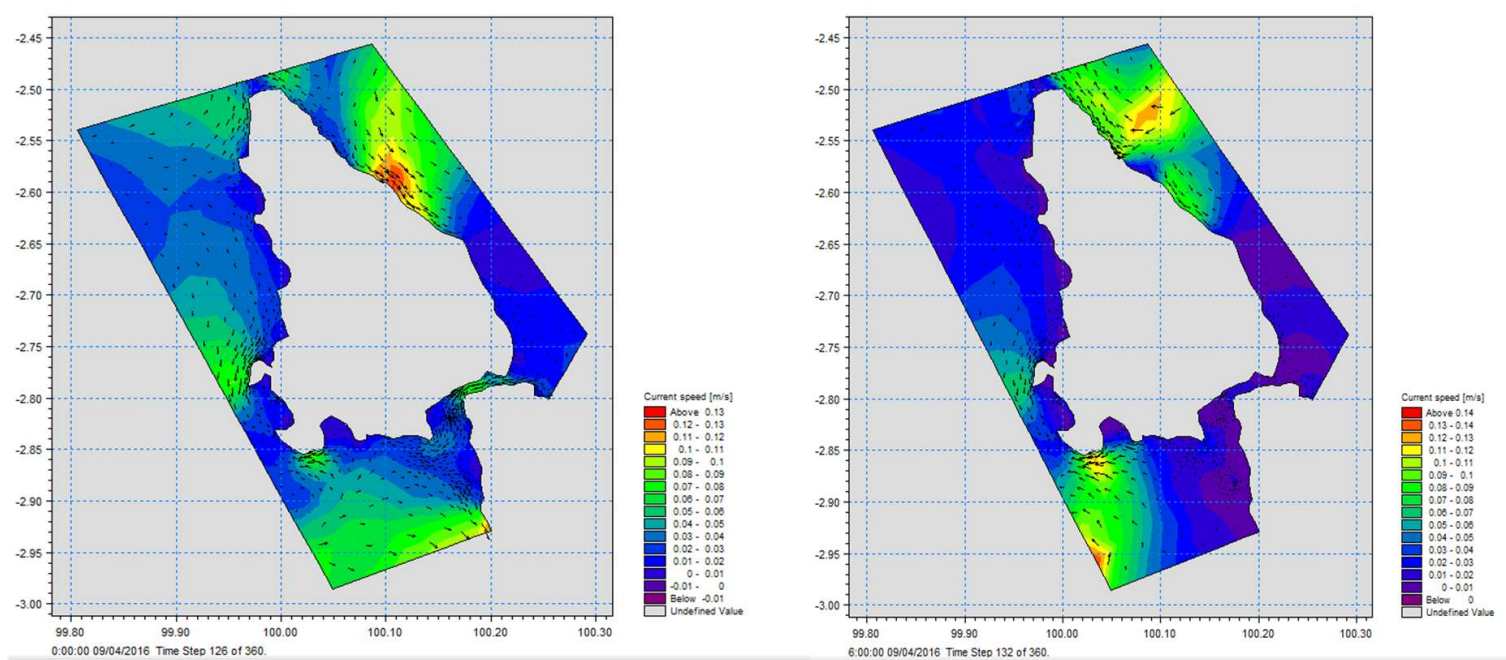

FIGURE 7. Direction and Velocity of Current around The North Pagai Island and The Pagai Strait [8]

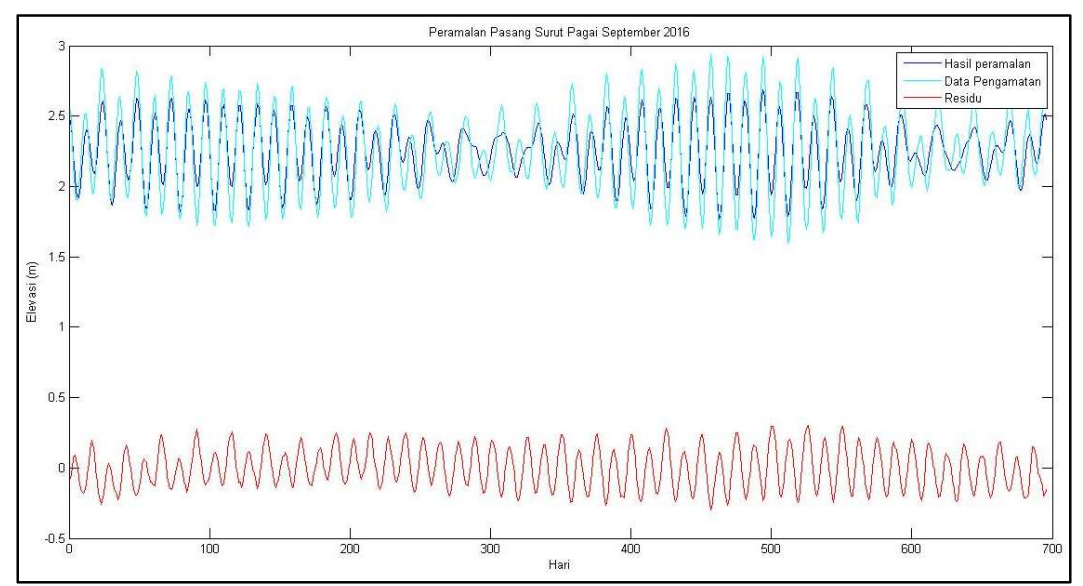

FIGURE 8. Type of Tidal in The Pagai Strait [8]

TABEL 1. Distribution of TDS and Sediment based on diameter, type and specific gravity

\begin{tabular}{llrrrrrrrr}
\hline No & Sta & $\begin{array}{c}\text { TDS } \\
(\mathrm{mg} / \mathrm{L}\end{array}$ & $\begin{array}{c}\text { Gs } \\
\left(\mathrm{gr} / \mathrm{cm}^{3}\right)\end{array}$ & $\begin{array}{c}\mathrm{D}_{35} \\
(\mathrm{~mm})\end{array}$ & $\begin{array}{c}\mathrm{D}_{50} \\
(\mathrm{~mm})\end{array}$ & $\begin{array}{c}\mathrm{D}_{90} \\
(\mathrm{~mm})\end{array}$ & $\begin{array}{c}\text { Gravel } \\
(\%)\end{array}$ & $\begin{array}{c}\text { Sand } \\
(\%)\end{array}$ & \multicolumn{1}{c}{$\begin{array}{c}\text { Clay } \\
(\%)\end{array}$} \\
\hline $\mathbf{1}$ & Sta 2.1 & 54.3 & 2.657 & 0.28 & 0.395 & 2.800 & 5.294 & 87.206 & 7.50 \\
\hline $\mathbf{2}$ & Sta 2.2 & 51.6 & 2.665 & & & & 0 & 1.25 & 98.75 \\
\hline $\mathbf{3}$ & Sta 2.3 & 54.5 & 2.667 & 0.073 & 0.110 & 0.290 & 0 & 63.60 & 36.40 \\
\hline $\mathbf{4}$ & Sta 2.4 & 54.4 & 2.658 & 0.19 & 0.605 & 4.300 & 6.40 & 72.50 & 21.10 \\
\hline $\mathbf{5}$ & Sta 2.5 & 54.4 & 2.663 & 0.058 & 0.090 & 0.400 & 1 & 56.033 & 42.967 \\
\hline $\mathbf{6}$ & Sta 2.6 & 54.4 & 2.666 & 0.088 & 0.120 & 0.315 & 0 & 77.632 & 22.368 \\
\hline $\mathbf{7}$ & Sta 2.7 & 54.6 & 2.671 & 0.025 & 0.067 & 0.250 & 0 & 77.632 & 22.368 \\
\hline $\mathbf{8}$ & Sta 2.8 & 54.6 & 2.653 & 0.33 & 0.697 & 6.400 & 16.767 & 64.967 & 18.267 \\
\hline $\mathbf{9}$ & Sta 2.9 & 54.6 & 2.674 & 0.008 & 0.019 & 0.150 & 0 & 16.567 & 83.433 \\
\hline $\mathbf{1 0}$ & Sta 2.10 & 54.6 & 2.679 & 0.05 & 0.016 & 0.067 & 0 & 6.200 & 93.80 \\
\hline $\mathbf{1 1}$ & Sta 2.11 & 54.6 & 2.658 & & & 0.150 & 0 & 25.250 & 74.75 \\
\hline $\mathbf{1 2}$ & BBI & & 2.668 & & 0.13 & 1.40 & 0 & 55.429 & 44.571 \\
\hline $\mathbf{1 3}$ & P. Ragi & & 2.670 & 0.125 & 0.14 & 0.34 & 0 & 91.867 & 8.133 \\
\hline
\end{tabular}




\begin{tabular}{llllllrrrr}
\hline $\mathbf{1 4}$ & P. Siruso & & 2.669 & 0.096 & 0.12 & 0.38 & 0 & 85.235 & 14.765 \\
\hline $\mathbf{1 5}$ & Ttk.1 & 52.4 & 2.656 & 0.407 & 1.270 & 6.830 & 18.3 & 77.533 & 4.167 \\
\hline $\mathbf{1 6}$ & Ttk.2 & 54.1 & 2.656 & 0.200 & 0.240 & 0.385 & 0 & 97.133 & 2.867 \\
\hline $\mathbf{1 7}$ & Ttk.3 & 53.2 & 2.668 & 0.213 & 0.271 & 0.522 & 0 & 95.90 & 4.10 \\
\hline $\mathbf{1 8}$ & Ttk.4 & 54.2 & 2.669 & 0.205 & 0.247 & 0.400 & 0.267 & 97.433 & 2.30 \\
\hline $\mathbf{1 9}$ & Ttk.5 & 54.1 & 2.666 & 0.200 & 0.246 & 0.392 & 0 & 97.467 & 2.533 \\
\hline $\mathbf{2 0}$ & Ttk.6 & 55.0 & 2.657 & 0.150 & 0.380 & 6.900 & 19.167 & 55.967 & 24.867 \\
\hline $\mathbf{2 1}$ & Ttk.7 & 53.3 & 2.679 & 0.091 & 0.120 & 0.310 & 0 & 77.771 & 20.229 \\
\hline $\mathbf{2 2}$ & Ttk.8 & 54.6 & 2.661 & 0.240 & 0.350 & 1.100 & 4 & 91.30 & 4.70 \\
\hline $\mathbf{2 3}$ & Ttk.9 & 54.6 & 2.67 & 0.076 & 0.160 & 0.540 & 1.024 & 64.314 & 34.661 \\
\hline & Average & & 2.665 & 0.155 & 0.273 & 1.573 & 3.139 & 66.877 & 29.982 \\
\hline
\end{tabular}

The grain size analysis shows that average diameter of sediment is $\mathrm{D}_{90}$ size $1.57 \mathrm{~mm}\left(\mathrm{Gs}=2.665 \mathrm{gr} / \mathrm{cm}^{3}\right)$ and dominated by the sand about $66.88 \%$. TDS about 51.6 to $55.0(\mathrm{mg} / \mathrm{L})$. According to Environmental Ministry Decree No.51 year 2004, the TDS appropriate for ports $(80 \mathrm{mg} / \mathrm{L})$ and mangrove $(80 \mathrm{mg} / \mathrm{L})$ but not for coral dan seagrass $(20$ $\mathrm{mg} / \mathrm{L}$ ). The distribution of sediment based on grain size (diameter) as shown in figure 9 and the type of sediment as shown in figure 10 below.
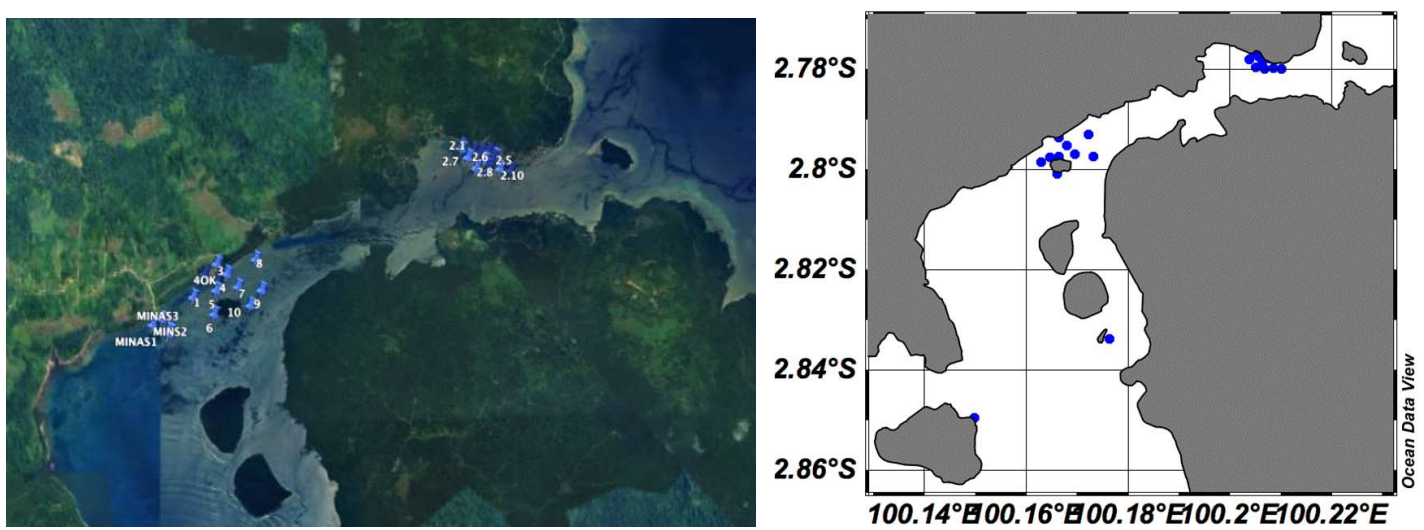

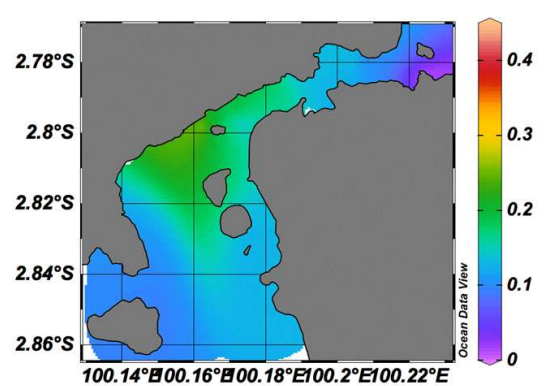

(a) Sediment $\mathrm{D}_{35}$

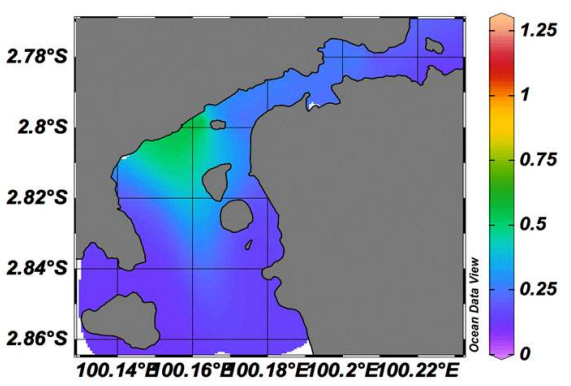

(b) Sediment $\mathrm{D}_{50}$

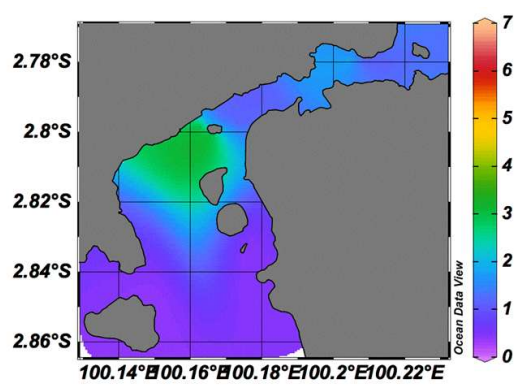

(c) Sediment $\mathrm{D}_{90}$

FIGURE 9. Distribution of Diameter Sediment at the Pagai Strait $\left(\mathrm{D}_{35}, \mathrm{D}_{50}\right.$ and $\left.\mathrm{D}_{90}\right)$

Based on figure 9, the composition of sediment is D90 $(1,573 \mathrm{~mm}), \mathrm{D} 50(0,273 \mathrm{~mm})$ and D35 $(0,155 \mathrm{~mm})$ and figure 10 shows the distribution of sand $(66,878 \%)$, clay $(29,982 \%)$ and gravel $(3,139 \%)$. 


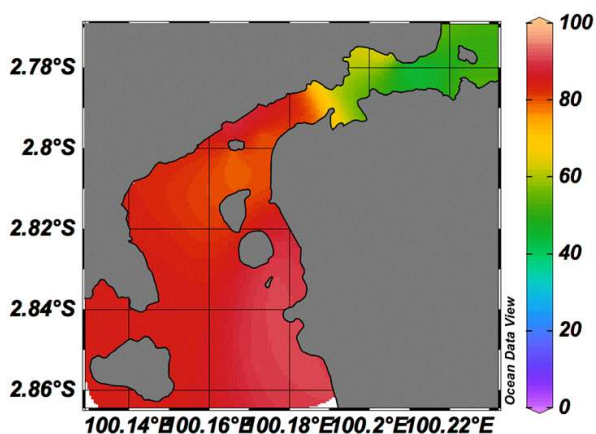

(a) Sand

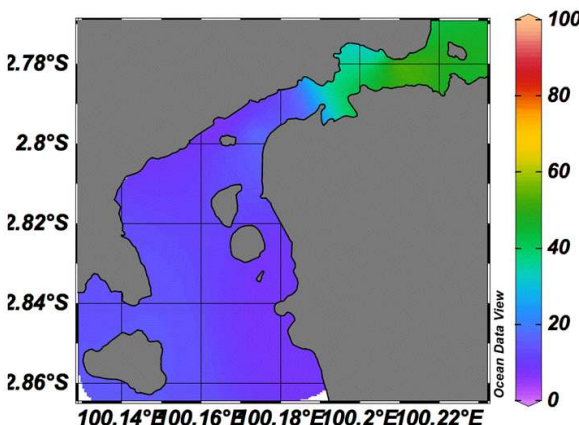

(b) Clay

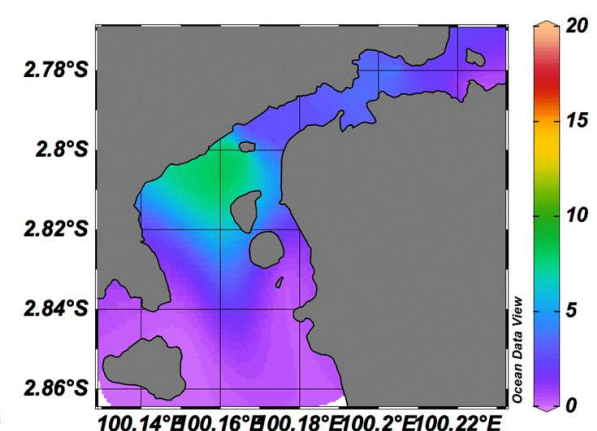

(c) Gravel

FIGURE 11. Distribution of Sediment Type at the Pagai Strait (Sand, Clay and Gravel)

\section{Sediment Transport at The Pagai Strait}

1. Velocity of Particles, USACE (2000) :

Median sediment size $\mathrm{D}_{50}=0.273 \mathrm{~mm}$. Figure 11 , we get sediment scale for $\mathrm{D}_{50}, \mathrm{~A}=0.119$. Therefore, the velocity of sediment particle $\mathrm{wf}=0.2 \mathrm{~cm} /$ second or $0.002 \mathrm{~m} / \mathrm{second}$ (figure 12 ).

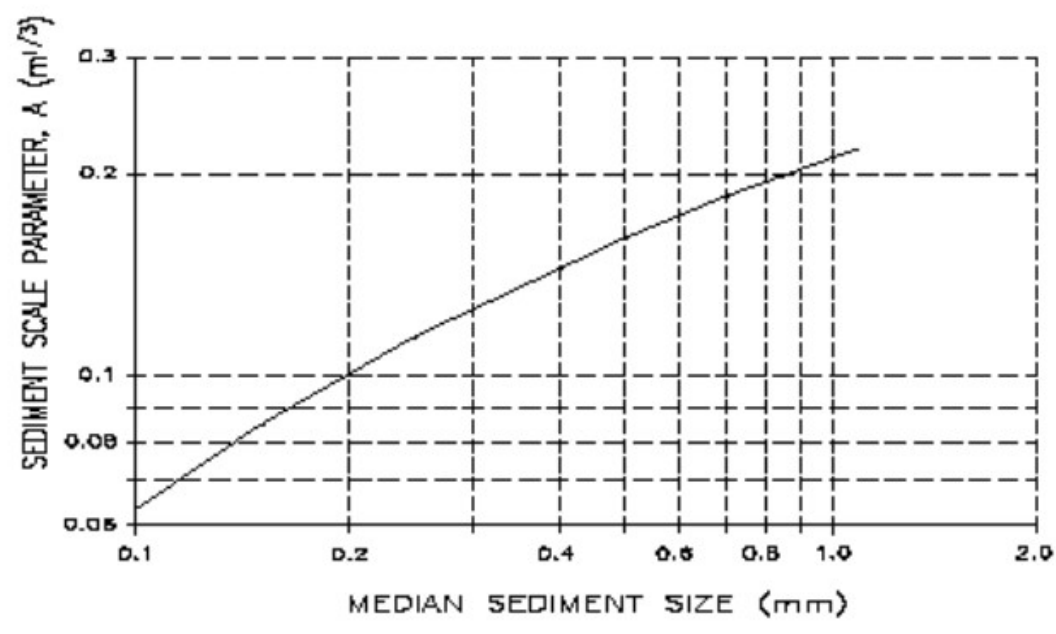

FIGURE 12. The Relation between Sediment Scale Parameter (A) with Median Sediment Size (D 50 ) [9] 


\begin{tabular}{|c|c|c|c|c|c|c|c|c|c|c|}
\hline $\mathrm{D}(\mathrm{mm})$ & 0.00 & 0.01 & 0.02 & 0.03 & 0.04 & 0.05 & 0.06 & 0.07 & 0.08 & 0.09 \\
\hline 0.1 & 0.063 & 0.0672 & 0.0714 & 0.0756 & 0.0798 & 0.084 & 0.0872 & 0.0904 & 0.0936 & 0.0968 \\
\hline 0.2 & 0.100 & 0.103 & 0.106 & 0.109 & 0.112 & 0.115 & 0.117 & 0.119 & 0.121 & 0.123 \\
\hline 0.3 & 0.125 & 0.127 & 0.129 & 0.131 & 0.133 & 0.135 & 0.137 & 0.139 & 0.141 & 0.143 \\
\hline 0.4 & 0.145 & 0.1466 & 0.1482 & 0.1498 & 0.1514 & 0.153 & 0.1546 & 0.1562 & 0.1578 & 0.1594 \\
\hline 0.5 & 0.161 & 0.1622 & 0.1634 & 0.1646 & 0.1658 & 0.167 & 0.1682 & 0.1694 & 0.1706 & 0.1718 \\
\hline 0.6 & 0.173 & 0.1742 & 0.1754 & 0.1766 & 0.1778 & 0.179 & 0.1802 & 0.1814 & 0.1826 & 0.1838 \\
\hline 0.7 & 0.185 & 0.1859 & 0.1868 & 0.1877 & 0.1886 & 0.1895 & 0.1904 & 0.1913 & 0.1922 & 0.1931 \\
\hline 0.8 & 0.194 & 0.1948 & 0.1956 & 0.1964 & 0.1972 & 0.198 & 0.1988 & 0.1996 & 0.2004 & 0.2012 \\
\hline 0.9 & 0.202 & 0.2028 & 0.2036 & 0.2044 & 0.2052 & 0.206 & 0.2068 & 0.2076 & 0.2084 & 0.2092 \\
\hline 1.0 & 0.210 & 0.2108 & 0.2116 & 0.2124 & 0.2132 & 0.2140 & 0.2148 & 0.2156 & 0.2164 & 0.2172 \\
\hline \multicolumn{11}{|c|}{$\begin{array}{l}\text { Notes: } \\
\text { (1) The } A \text { values above, some to four places, are not intended to suggest that they are known to that accuracy, but rather } \\
\text { are presented for consistency and sensitivity tests of the effects of variation in grain size. } \\
\text { (2) As an example of use of the values in the table, the } A \text { value for a median sand size of } 0.24 \mathrm{~mm} \text { is: } A=0.112 \mathrm{~m}^{13} \text {. To } \\
\text { convert } A \text { values to feet units. multiply by } 1.5 \text {. }\end{array}$} \\
\hline
\end{tabular}

FIGURE 13. Recommendation of A value Based on Grain Size D50 [9]

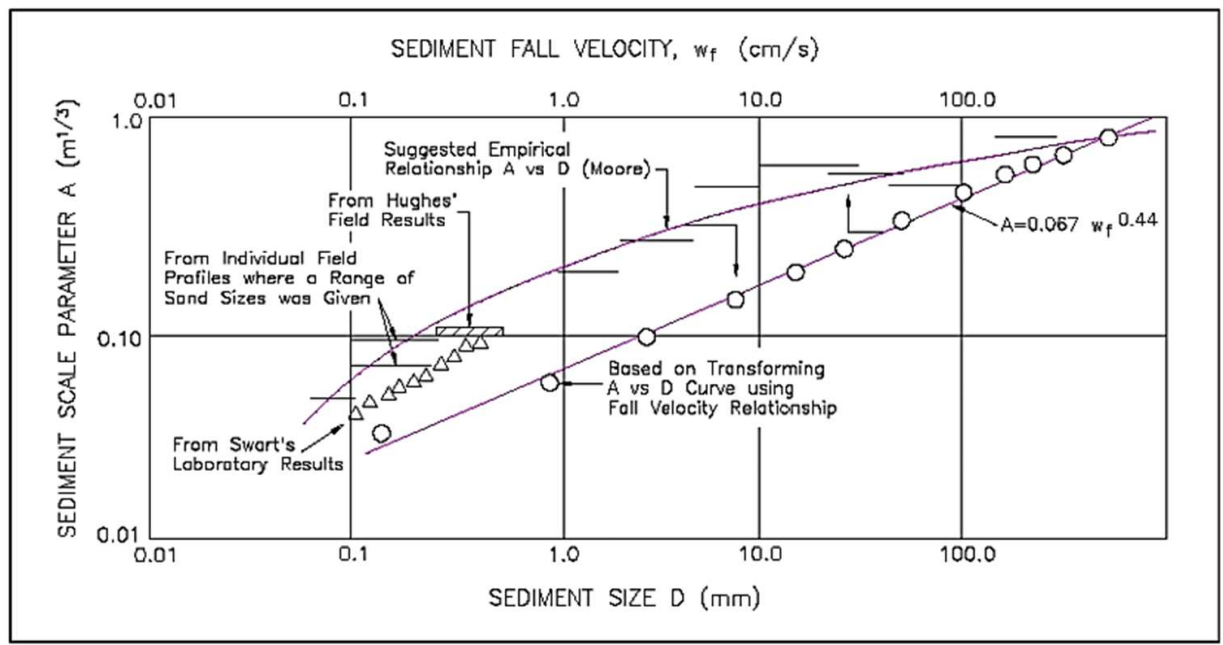

FIGURE 14. The Relation Parameters between A, wf and $\mathrm{D}_{50}$ [9]

2. Profile of balanced coastal, Dean (1977):

$$
\begin{gathered}
h=f\left(A^{n}\right) \ldots \ldots \ldots(3) \\
h=f(A)^{\frac{2}{3}}=\left(\frac{24}{5} \frac{D}{\rho g K^{2} \sqrt{g}}\right)^{\frac{2}{3}} \ldots \ldots \ldots .
\end{gathered}
$$

and $K=1,4 e^{\left(-2,5 D_{50}\right)}$

If $\mathrm{A}$ is a function of wf, then:

$$
h=2.25\left(\frac{w f^{2}}{g}\right)^{\frac{1}{3}}
$$

with:

$\mathrm{h}=$ profile of balanced coastal $(\mathrm{m})$

$\mathrm{A}=$ Parameter of sediment scale, function of D50

$\mathrm{n}=2 / 3$ 


$$
\begin{gathered}
h=2,25\left(\frac{0,00119^{2}}{9,18}\right)^{\frac{1}{3}} \\
h=0,113872 \mathrm{~m}
\end{gathered}
$$

3. Volume of sediment transport, CERC and CEM (2002):

with:

$$
Q s=0,014 x \mathrm{Hs}^{2} x \operatorname{cox} x \mathrm{kr}^{2} x \sin \alpha x \cos \alpha
$$

Qs = volume sediment transport ( $\mathrm{m} 3 / \mathrm{second})$

$\mathrm{Hs}=$ height of significant waves $(\mathrm{m})$

co $=$ velocity of wave $(\mathrm{m} /$ second $)$

$\mathrm{kr}=$ refraction coefficient

$\alpha=$ angle of break wave

Data (RICRV, 2016):

$\mathrm{Hs}=2,06 \mathrm{~m}$

$$
=0,032716^{\circ}
$$

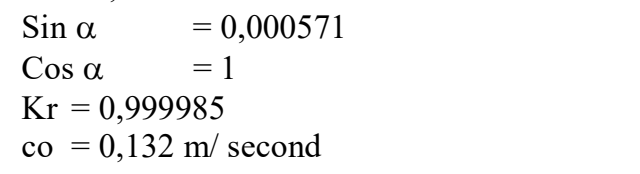

$$
\begin{gathered}
Q s=0,014 \times \mathrm{Hs}^{2} \times \operatorname{cox} \times \mathrm{kr}^{2} \times \sin \alpha \times \cos \alpha \\
Q s=0,014 \times 2,06^{2} \times 0,1327894 \times 0,999985^{2} \times 0,000571 \times 1=0,000004505 \\
\text { Qs }=0,000004505 \mathrm{~m}^{3} / \mathrm{second}^{\mathrm{s}} 24 \times 60 \times 60 \\
\text { Qs }=0.389 \mathrm{~m}^{3} / \text { day }
\end{gathered}
$$

\section{CONCLUSION}

The result shows that the characteristics of sediment is mostly $\mathrm{D}_{90}$ with size $1.57 \mathrm{~mm}$; specific gravity $2.665 \mathrm{gr} / \mathrm{cm}^{3}$; and dominated by sand $66.88 \%$. TDS about 51.6 to $55.0(\mathrm{mg} / \mathrm{L})$ appropriate for port and mangrove. The velocity of sediment particles is $0.002 \mathrm{~m} / \mathrm{s}$ and the volume of sediment transport is $0.389 \mathrm{~m}^{3} /$ day approximately.

\section{REFERENCES}

[1] Coastal Engineering Manual (CEM). "Part III. Coastal Sediment Processes". EM. 1110-2-1100.2002

[2] Stull, T. "Physical Characteristics of Perth Beaches. Western Australia". The University of Western Australia. Crawley. West Australia. 2006

[3] CERC. "Wave energy Utilization in Europe: Current Status and Perspectives". European Thematic Network on Wave Energy. Greece. 2002

[4] Briggs, R.W., Sieh, K., Meltzner, A.J., Natawidjaja, D., Galetzka, J., Suwargadi, B., Hsu, Y.-j, Simons, M., Hananto, N., Suprihanto, I., Prayudi, D., Avouac, J.-P., Prawirodirdjo, L., Bock, Y. "Deformation and slip along the Sunda mega-thrust in The Great 2005 Nias-Simeulue Earthquake". Science 311,1897-1901. 2006

[5] Konca, A.O., Avouac, J.-P., Sladen, A., Meltzner, A.J., Sieh, K., Fang, P., Li, Z., Galetzka, J., Genrich, J., Chlieh, M., Natawidjaja, D.H., Bock, Y., Fielding, E.J., Ji, C., Helmberger, D.V. "Partial Rupture of A Locked Patch of The Sumatra Megathrust During The 2007”. Earthquake sequence. Nature456,631635.http://dx.doi.org/10.1038/nature.07572. 2008

[6] Shearer, P., Bürgmann, R. "Lessons learned from the 2004 Sumatra Andaman megathrust rupture". Annu.Rev.EarthPlanet.Sci.38,103-131.http://dx.doi.org/10.1146/annurev-earth-040809-152537. 2010

[7] Hill, E.M., Borrero, J.C., Huang, Z., Qiu, Q., Banerjee, P., Natawidjaja, D.H., Elosegui, P., Fritz, H.M., Suwargadi, B.W., Pranantyo, I.R., Li, L., Macpherson, K.A., Skanavis, V., Synolakis, C.E., Sieh, K. “The 2010 
MW 7.8 Mentawai Earthquake: Very Shallow Source of A Rare Tsunami Earthquake Determined from Tsunami Field Survey and Near-Field GPS Data". J.Geophys. Res. 117, B06402.http://dx.doi.org/10.1029/2012JB009159. 2012

[8] Herdiana Mutmainah, Rizki Anggoro Adi, Aprizon Putra, Try Altanto, Ulung Jantama Wisha, Whisnu Arya Gumilang, Ilham Adnan, Mugiyanto, Prima Sahputra and Ilham Tanjung. "Final Report of Coastal Resources and Vulnerability Research at North Pagai Island Year 2016". Research Institute of Coastal Resources and Vulnerability (RICRV,MMAF). Padang. West Sumatera. 2016

[9] USACE. “Coastal Engineering Manual”. Department of The Army Corps. Washington DC. 2000. 